\title{
Reflective Core Values of Sundanese Life: An Integration Inculcates the Value of Delays in the Environment of Pasundan University
}

\author{
Asep Sjamsulbachri and Deni Zein Tarsidi \\ Faculty of Teacher Training and Education \\ Universitas Pasundan \\ Bandung, Indonesia \\ asepsjamsulbachri123@gmail.com
}

\begin{abstract}
The reality of Indonesia that has a diversity of ethnic cultures and cultures and different religions, one of the second largest ethnics is Sundanese which certainly has a unique value of civilization but still sticking in the corridors of the Unitary State of the Republic of Indonesia. This research uses phenomenology method, with data collection technique through observation, interview and documentation analysis. The moral values of Sundanese culture that are implemented in campus life can create harmony among the leaders, lecturers, employees and students, so that the harmonious atmosphere among students in their campus life when they come from various ethnic and religious and also different culture, even many foreign students' study here, both undergraduate-postgraduate degree. The existence of Sunda Core Value crystallized in the motto luhung elmuna (high science), pengkuh agamana (strong religion), jembar budayana (cultural fields) for every graduate, its distinctive mission of maintaining Sundanese culture and glorifying syiar islam, appearing in campus atmosphere, tolerance of mutual respect among them and Silih Asih (Love each other), Silih Asah (mutual competition), Silih Asuh (Alternate care) reflects the atmosphere of life spiritually Pancasila, which became the Core Value Nation of Indonesia.
\end{abstract}

Keywords - core values; community; sundanese

\section{INTRODUCTION}

Globalization is a fact that we cannot deny again so that knowledge and technology into two things that cannot be separated from each other. According to [1], the keyword of globalization is competition. So that globalization provides opportunities and facilities for all people willing and able to use them for both self and human interest. Globalization has penetrated all over the world and even into remote areas, capable of breaking through the gates of moral and religious defense as strongly as it is preserved. Morality is loosened by something once tabooed, it is now a matter of course. How to dress, interact with the opposite sex, enjoy drugs and entertainment places become one of the trends of the modern world that is difficult to overcome.

Family life and Sundanese people, especially those living in urban areas, are experiencing a change due to the rapid flow of globalization. In connection with the form of culture as a complex of ideas and ideas, complex patterned activities and social systems with human works that must be maintained also preserved the shift of cultural values can be categorized as a very worrying phenomenon. Sundanese ethnic is a native of Pasundan land that has characteristics of culture, language, religion, tradition, livelihood, as well as various unique cultural heritage of ancestors. For Sundanese people the moral values of Sundanese culture are a solid fortress to face the changing times in this era of globalization.

Prior to independence, Indonesia in its cultural history had gone through periods of great empires and colonies that spanned in a matter of centuries, greatly affecting the world of education, especially character education. During the Dutch colonial period, indigenous people known as boemi poetra were given limited opportunities in education. Through ethical politics, the Netherlands only allows certain natives who can obtain formal education.

The cultivation of the character of the nation, especially in the Sundanese region, at that time was more informally done, as seen in the purpose of planting the values that parents should teach their children ngomean adat bawa ti koedrat soepaya toeloey-toeloey tepi ka kolot salamet, kadeuleu koe sanak baraya, ari geus kolot eta boedak tangtoe di regepkeun papatahna, di toeroetan kalakoeanana, which means: "Character Education to improve the congenital innate attitudes to be good so that his life survived to old age and his practice and exemplary by his family [2].

While in formal education one form of struggle of the Sundanese community is through Paguyuban Pasundan (1913) which has the purpose of education Pasundan namely: anoe djadi poko loeloegoe djudul atikan njeeta ngawangun pamake baroedak soepaja djadi djelama sampoerna, maksoedna awewe lalaki waspada, matang pamilih, pangadjen, koekoeh enggoning njieun poetoesan, temen wekel di pake ageman, kalajan satia kana poetosan pribadi dina enggoning roemingkang saliring doemadi, which means: "The purpose of education is to build the character of children to become perfect human beings both men and pedestals with a steady attitude of personality alert, dignity, firm stance and loyal to personal messengers in the face of life [3] 
The world of education should help children to understand the core value, embrace and practice it in their lives, because ultimately the individual character will form the character of society which will in the future characterize the character of a nation.

\section{THEORETICAL}

Values are at the core of the cultural system. It is as Du Weming (in Lutan) says, that the core of culture is made up of traditional concepts in general and value systems in particular. 'Value in a culture, when there is a change in value there are changes cultures including attitudes and human behavior in the life of society, nation, and state [4]. According to Gazali, et al. (1997) that: Cultural value is an abstract conception of a very important and valuable basic issue in the life of human society. A cultural value system consists of several elements: religious values, value of knowledge, social value, economic value, art value. Religious values are the foundation of cultural formation. The value of knowledge involves logical and rational reasoning in proving something right or wrong. Social value that is related to the love between human beings such as mutual assistance, tolerance, tolerance, and others. The economic value of assessing profit and loss. While the value of art that is associated with beauty and harmony. According to Amin (2011) that: The results of creation, intention, and work of high art value, the value of its beauty, its ornament value reflects the high culture, reflects the quality of creation and work, reflects the high quality, and also reflects the high dignity and the character of the nation's children. Therefore, to achieve the character of the nation's dignified children then in need of high cultural values in terms of art, beauty and ornament. Human reason is the tool used in creating the values that form the basis in behaving that is related to human culture. Spranger (in Lutan) outlines his concept that human values can be distinguished in:

- Value theory, as incarnate in science and knowledge;

- The economic value commonly called utility;

- The value of religion in the form of holiness or holiness;

- The aesthetic value is called expressiveness or expression;

- Vertical social values of power that are primarily transformed into political behavior and communication;

- The horizontal social value of solidarity that is incarnated as love, friendship and cooperation. [4]

Based on these values the dominant value is the value of religion that subdues all other values to logic, law and reality. The values contained in the culture are reflected in the behavior of every human being. It is as revealed by Lutan that "most social activities in a society are directed or controlled by culture, values and norms" [4]. Local cultural values are interpreted as social identities that need to be communicated or delivered to the community. Values are seen as something valuable by a person or group of people and be used as a reference of action and direction of life.
Cultural values derived from the learning process produce certain attitudes and behaviors that can build the character of the nation. Koentjaraningrat (in Lutan) explains that a cultural value system suitable for development includes:

- Active attitude, endeavor and not fatalistic;

- Orientation to work, improvement of work;

- Orientation of nature;

- Future orientation of life;

- Orientation of cooperation. [4]

These five values orientations are suitable for development including in national development in order to maintain the character of the Indonesian nation. Soekarno (1995) said that the moral values of Sundanese culture are the identity of Sundanese ethnic originating on values, beliefs and cultural heritage of Sunda and referred in behaving. For Sundanese people the moral values of Sundanese culture are a solid fortress to face the era of globalization. According to the moral values of Sundanese culture are the values possessed by the Sundanese people who are believed to be their outsiders and cause the Sunda community's determination to make it happen [5]. It contains the basic concept of life formed by the people and the Sundanese people. Systematically illustrated in the following figure:

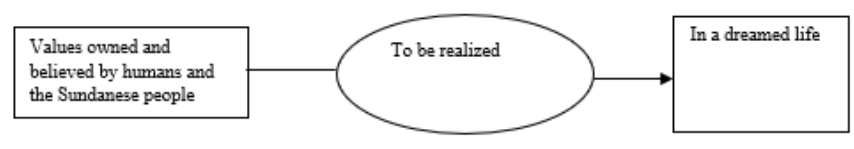

Fig. 1. Systematical realization of value on sundanese society.

a. Processed by: Rusyana (2001: 16)

This process will last a lifetime through education, both formal and informal education by family and community.

The emphasis of formal and informal educational objectives is on the formation of character through exemplary in the personal context as well as in community life, safe in relationships horizontally and vertically.

With education, it will arise in a person to compete and motivate ourselves to be better in all aspects of life. Education is one of the conditions to further advance this government, then try education from elementary to university level.

The purpose of National Education in the 1945 Constitution (Article Amendment), Article 31, Paragraph 3 states, "The Government seeks and organizes a national education system, which enhances faith and piety and noble moral in order to educate the nation's life, which is regulated by law." , Article 31, paragraph 5 states, "The government advances science and technology by supporting the high values of religion and national unity for the advancement of civilization and the welfare of mankind" [6]

While the National Education Objectives in Law no. 20, Year 2003, Article 3 states, "National education functions to develop the ability and form the character and civilization of a 
dignified nation in order to educate the nation's life, aims for the development of potential learners in order to become a man of faith and cautious to God Almighty, healthy, knowledgeable, capable, creative, independent, and become a democratic and responsible citizen" [7].

The effort to establish the character of the nation in its implementation must be in harmony with the nuances of the pluralistic potential of the people, so that there will be a form of identity of the nation of Indonesia in diversity rides which can minimize the incidence of ethnic, cultural and religious jealousy and avoid the disintegration of the nation [8].

The formation of character and character of the nation through education is emphasized on the appreciation and practice of moral values, the capability and tillage as well as the cultivation of discipline and habitualization of a commendable attitude. The emphasis on these three aspects is a form of developing affective, cognitive and psychomotor spheres proportionally and equally.

\section{METHOD}

Methodologically, this research will use qualitative paradigm with phenomenology research design. The tradition of the Phenomenological study, according to Creswell, is: "Whereas a biography reports the life of a single individual, a phenomenological study describes the meaning of the live experiences for several individuals about a concept or the phenomenon" [9].

According to Arikunto states that "the subject of research is the object, thing or organization where the data or research variables in question attached" [10]. No research can be done without a research subject. The subject of the study is the source that can provide information on the problems that the author thoroughly. According to Miles and Haberman states that "in determining the subject of the study, there are several criteria used: setting, actors, events, and processes" [11].

Data collection techniques through: interviews, observations and documentary studies of students, lecturers, leaders, and employees of Pasundan University.

Because this study belongs to the category of phenomenological studies, the flow of data analysis follows what Creswell says, as follows:

- The researcher begins by thoroughly describing his experience

- The researcher then finds a statement (in an interview) about how people understand the topic, detailed the statements and treat each statement equally, and develop the details by not repeating or overlapping.

- The statements are then grouped into meaning units, the researcher specifies the units and writes a textural description of his experience, including examples thoroughly.

- The researcher then reflects on his thinking and uses imaginative variation or structural description, seeks all possible meanings and through divergent perspectives, considers the phenomenon reference frame, and constructs the phenomenon is experienced.

- The researcher then constructs all his explanation of the meaning and essence of his experience.

- The process is the first step the researcher expressed his experience, and then followed the experience of all participants. After all that is done, then write a composite description [9].

\section{RESUlt AND DisCUSSION}

The moral values of Sundanese culture are lifted from various traditional expressions in the form of proverbs of various folklore, petatah petitih, etiquette and kepamalian (taboo) yang dikaji dari sumber masa Prabu Siliwangi, naskah kuno masa Kerajaan Sumedang, nilai moral masyarakat Baduy. Hasil penelitian tradisi lisan sastra sunda [5], hasil penelitian makna folklore sunda [12].

Altogether directed to the five values of human relationships in his life according to the results of research Warnaen concerning moral values [13].

\section{A. Human relationship with god}

Human relationships with gods are the ones crystallizing on the behavior of diversity held especially in predominantly faith-dominated Islam sunah waljamaah. Believed by all elements in the Unpas environment, communication beliefs among them are tolerant and flexible.

\section{B. Human relationship with the person}

It crystallizes in tolerance, and dislikes the affairs of others, and personal affairs are not mixed with the life of the campus, other religious affairs are closed.

\section{Human relationship with the community}

In general, other ethnic students influenced Sundanese culture, especially speaking and ethical and dressed especially in the academic community there is dedication.

\section{Human relationship with nature}

In all of the campus life line both the activities of leaders, employees, lecturers, students at first, they are very nurturing the natural environment. Unpas has a tradition of Dies Natalies greening the natural forest of citarum river springs, lecturers, employees, ordinary nature tour, student organization of nature pencak (Mapak Alam Unpas) many achievement.

\section{E. Human relations with the fulfillment of the needs of the birth and the mind}

Almost all college life, both leaders, lecturers, employees, and college students appear to be inconspicuous in their lives, almost nobody is involved in corruption, moneylenders or unethical behavior in meeting their inner needs by campus cantons, lecturers' clothes and uniformed employees and every date 14 two months once there is a loyalty ceremony with leadership direction and spiritual splash. 


\section{F. Empowerment of Sunda cultural institutions (LBS)}

The empowerment of LBS is instrumental in serving the fulfillment of the inner needs of leaders, lecturers, employees who want to learn Sundanese art, at this time for lute, drum, and degung there is a class for foreign students in writing final assignment using three languages (Indonesian, English and Sundanese).

\section{G. Empowerment of LP2SI (Institute for the Assessment and Spreading of Islamic Shari'a)}

LP2SI is very helpful for students who are Muslims but cannot read the Quran they study in Unpas mosque, the name of the mentoring activities coordinates MPK Islam and Islam Discipline Science that studies Islam according to the discipline of science indirectly controls the attitude of Islam is intolerant.

The visible attitudes of the empowerment of these two institutions brought the atmosphere of a peaceful, tolerant, mutually compassionate and respectful campus of Unpas, including the large family of Pasundan University, although different religions.

The values to be implemented are silas, cageur, bageur, bener, pinter, wanter, nanjeur and Islamic values akhlakul karimah [14]. In towards the Trijatidiri luhung elmuna, pengkuh agamana, jembar budayana.

Silas who became the national motto derived from the slogan of West Java Governor, Sanusi Hardjadinata (1950) when in West Java turmoil occurred. The value of cageur, bageur, bener, pinter, wanter is NMBS proposed by Raden Dewi Sartika at your wife's school in 1932 [15].

In the guidance of Vision-Mission for Lecturers 1997 value of Trijatidiri Unpas referred from Al-Quran is from the letter:

- Surat Al-Imran :7-191

- Surat An-Nisa :192

- Surat Al-An'am :161-163

- Surat Al-Hujorot: 13

- Surat An-Anfal: 2-3

- Surat Al-Anbiyya: 105

- Surat At-Taubah: 75

Theoretically, Trijatidiri was extracted from Sundanese cultural values and confirmed by the Qur'an [15]. Luhung elmuna reviewed from Sanghyang Siksa Kandung Karesian which was prepared 1518 introduced by K.F Hole (1867). To Sanghyang Siksa Kandung Karesian, Ayatrohaedi mentions as the guidance of life and knowledge source of the Sundanese (2003) as for luhung elmuna reviewed from Amanat Galunggung, sheet V Rekto: 2 yang berbunyi rapes dina oerang agama ni pare-masana djoemaroen teuleu daoen masana diojas-gede pare-masana boeloe ireong-beukahtarakah-noenjoenk lalangit, which means: "As for perfect deeds is the science of rice: at the time of sprouting as the needle, the leaves, when weeded grow up, the bud out, the fruit blooms pointed sky looking up, beautiful, after containing arrived when ducked, yellowing, after the sides [16].

Pengkuh Agamana can be studied from Amanat Galunggung V Verso: 3 which reads: ngasupkeun hulun jarang midukaan, nanya kanu karwlwat mawa toeh sabab na agama pun, sasana buat kwalwat pun hana nguni hana mangke. Which means: "ask the parents, undoubtedly will not be despised, astray from religion, that is the law of the ancestors, there used to be now [16].

Jembar Budayana can be studied from Amanat Galunggung VI Verso: 2 which reads: nu takut sapa, nurut dina menak di gusti panghulu, reya kabisa, prijnya, cangcingan, gapitan iya galah condok tinugelan teka ngarana. Which means: "those who fear, obey the noble ones, the landowners and the rulers, have many skillful, intelligent, skillful, skillful, like piercings cut in their pointed names, not wasting our good deeds if so. [16].

Harmonization of Pancasila With Morals, the results of thinking in relation to the core value of the nation of Pancasila with morals as a code of ethics behave that looks as follows:

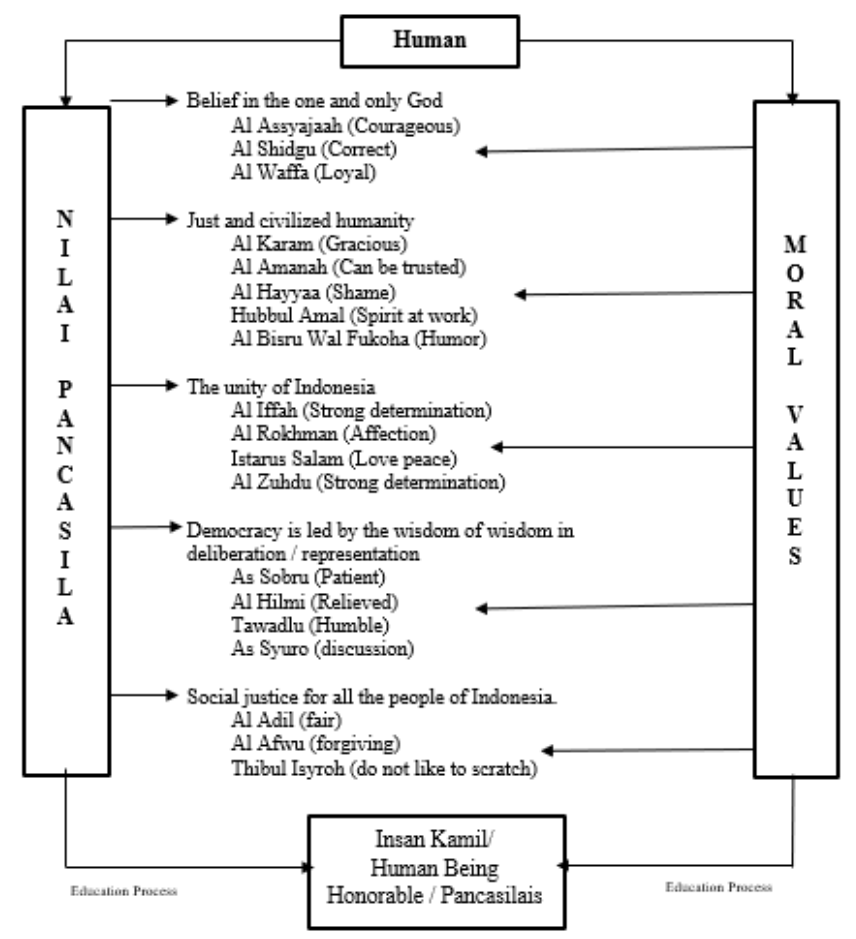

Fig. 2. Relation to the core value of the nation of pancasila with morals as a code of ethics

- The atmosphere of a harmonious campus life gave birth to a flavored communication that gave birth to sympathetic and friendly behavior in the campus environment.

- The atmosphere of this harmonious campus life encourages students to learn well. Cultural moral values as core value is very important. 


\section{CONCLUSIONS}

Based on the above exposure, it can be concluded as follows:

- The atmosphere of Pasundan University campus life in the sense of communication between the leaders, lecturers, employees, and students harmonious shows signs of tolerance society that can ward off narrow primordialism and radicalism.

- The existence of two institutions LBS (Institute of Sundanese Culture) and LP2SI (Institute for Assessment and Spreading Syiar Islam) in Unpas menyemai adhesive power of individuals, ethnic, and nation that needs to be developed.

- The need for engineering to maintain a good atmosphere and complete something that is still lacking so that core value Sunda will strengthen the core value of the nation (Pancasila) which is an open ideology.

\section{REFERENCES}

[1] Azizy A. Qodri. Melawan globalisasi reinterpretasi ajaran Islam: persiapan SDM dan terciptanya masyarakat madani. Yogyakarta: Pustaka Pelajar. 2004.
[2] Mustafa, Hasan H. Adat Istiadat Oerang Soenda. Jogjakarta: Rekasarasin. 1913.

[3] Djadiningrat, PAA. Factoren Voor De Vooruitgang Van Indonesie. Djakarta: Commissie Redactie Pagoejoeban Pasoendan. 1939.

[4] Lutan, Rusli. Keniscayaan pluralitas budaya daerah analisis dampak sistem nilai budaya terhadap eksistensi bangsa. Bandung: Angkasa. 2001.

[5] Rusyana, Yus. Bagbagan Puisi Pupujian Sunda. Bandung: Proyek Penelitian Pantun dan Folklore Sunda. 1991.

[6] Undang-Undang Dasar Negara Republik Indonesia 1945 Amandemen IV.

[7] UU Nomor 20 Tahun 2003 Tentang Sistem Pendidikan Nasional

[8] Adimihardja, Kusnaka. Dialog Kebudayaan. Jakarta: ISPI Pusat. 1999.

[9] Creswell, John W., Qualitative Inquiry and Research Design: Choosing Among Five Traditions, Sage Publications Inc. USA. 1998.

[10] Arikunto, Suharsimi. Prosedur Penelitian.Jakarta : Rineka Cipta. 2006.

[11] Miles, Matthew B \& Hubermas, A Michael, Analisa Data Kualitatif, terjemahan, Rohidi, Tjetjep Rohendi, UI Press, Jakarta. 1992.

[12] Muis, Diana Nimpoeno. Makna Folklore Sangkuriang Sebagai Karya Sastra Lisan dan Fungsinya di Dalam Masyarakat Sunda. Desertasi Doktor Pada Universitas Padjadjaran. Bandung: unpublished.

[13] Warnean, Suwarsih. Pandangan Hidup Orang Sunda. Bandung: Dirjen Kebudayaan Depdikbud. 1987.

[14] SK. Rektor 023/Unpas.R/SK/Q///1997 tentang Pedoman Identitas Unpas.

[15] Ekadjati, Edi S. Kebudayaan Sunda. Jakarta: Pustaka Jaya. 1995.

[16] Atja, Salah Darsanasasmita. Amanat dari Galunggung. Bandung: Proyek Permusiuman di Jawa Barat. 1981. 